\title{
PENGARUH PENERAPAN STRATEGI KAIZEN TERHADAP TINGKAT KEPUASAN TAMU PADA HOTEL BUDGET DI KOTA MAKASSAR
}

\author{
Dian Puspita Chairunnissa \\ Mahasiswa Program Pascasarjana STIE Nobel Indonesia \\ e-mail : dianpchairunnissa@gmail.com
}

\begin{abstract}
This study aims to determine whether the kaizen strategy influences the level of guest satisfaction at the Budget Hotel in Makassar. Data collection uses primary data and secondary data obtained from questionnaires and. Samples taken amounted to 30 respondents. This study uses quantitative analysis methods, using multiple linear regression. The results obtained partially indicate that the variables seiri, seiton, seiso, and seiketsu have a significant effect on guest satisfaction while shitsuke has no significant effect. Simultaneously the variables seiri, seiton, seiso, seiketsu and shitsuke have a significant effect on guest satisfaction. Among the five variables, there is one variable that is the most dominant influence on guest satisfaction, namely the seiso variable. The results showed that the proposed hypothesis was accepted because it showed a positive and significant hypothesis test result. This means that the kaizen strategy has a positive and significant effect on the level of guest satisfaction at a Budget Hotel in Makassar.
\end{abstract}

Keywords: seiri, seiton, seiso, seiketsu, shitsuke and guest satisfaction.

\begin{abstract}
ABSTRAK
Penelitian ini bertujuan untuk mengetahui apakah strategi kaizen berpengaruh terhadap tingkat kepuasan tamu pada Hotel Budget di Kota Makassar. Pengumpulan data menggunakan data primer dan data sekunder yang diperoleh dari kuesioner dan. Sampel yang diambil berjumlah 30 responden. Penelitian ini menggunakan metode kuantitatif, melalui anlisa regresi linier berganda. Hasil yang didapatkan menunjukkan secara parsial bahwa variabel seiri, seiton, seiso, dan seiketsu berpengaruh signifikan terhadap kepuasan tamu sedangkan variable Shitsuke tidak berpengaruh signifikan. Secara simultan variabel seiri, seiton, seiso, seiketsu dan shitsuke berpengaruh signifikan terhadap kepuasan tamu. Diantara kelima variabel tersebut, terdapat satu variabel yang paling dominan berpengaruh terhadap kepuasan tamu yaitu variable seiso. Hasil penelitian menunjukkan bahwa hipotesis yang diajukan diterima karena menunjukkan hasil uji hipotesis yang positif dan signifikan. Ini berarti bahwa strategi kaizen berpengaruh positif dan signifikan terhadap tingkat kepuasan tamu pada Hotel Budget di Kota Makassar.
\end{abstract}

Kata kunci: seiri, seiton, seiso, seiketsu, shitsuke dan kepuasan tamu. 
PENDAHULUAN

Menurut data dari Perhimpunan Hotel dan Restoran Indonesia, saat ini peminat kamar hotel lebih banyak menyasar segmen hotel budget hal tersebut dapat dilihat segmen kelas ini lebih banyak dipilih pada kota-kota besar dan kota tujuan wisata. (http://www. jpnn.com/news/potensihotel-budget-besar tanggal akses 2 November 2018). Beberapa penelitian terdahulu terkait dengan kepuasan para pengguna hotel budget menunjukkan tingkat kepuasan yang cukup tinggi. Kepuasan pelanggan menjadi salah satu kunci sukses dari bisnis apapun termasuk bisnis perhotelan.

Untuk mempertahankan kualitas layanan dan kepuasan pelanggan diperlukan suatu upaya untuk melakukan perbaikan yang berkelanjutan, salah satu konsep perbaikan berkelanjutan yang berorientasi kepada pelanggan adalah konsep kaizen yang dikembangkan di Jepang. Dalam bahasa Jepang, kaizen berarti perbaikan berkesinambungan. Istilah ini mencakup pengertian perbaikan yang melibatkan semua orang (baik manajer maupun karyawan) dan melibatkan biaya dalam jumlah tak seberapa. Filsafat kaizen berpandangan bahwa cara hidup kita (apakah itu kehidupan kerja atau kehidupan sosial maupun kehidupan rumah tangga) hendaknya berfokus pada upaya perbaikan terus menerus (Imai, 1991).

Penerapan Kaizen sebagai Upaya mempertahankan kualitas layanan pada bisnis perhotelan diharapkan akan berdampak terhadap kepuasan tamu, strategi ini merupakan strategi yang berfokus pada perbaikan terus-menerus secara berkesinambungan dari semua level karyawan mulai dari level terendah sampai dengan manajemen puncak. Dengan perbaikan ke semua level tersebut, diharapkan para karyawan dapat meningkatkan mutu layanan sehingga mempengaruhi kepuasan tamu.

\section{KAJIAN TEORI}

Hotel budget merupakan konsep hotel dengan tarif ekonomis atau terjangkau dan memiliki fasilitas yang minim namun konsep tersebut tetap berkomitmen terhadap kualitas baik dari segi layanan yang diberikan oleh karyawan maupun fasilitas yang tersedia sehingga tamu tetap merasa puas.

Dalam mengembangkan industri pariwisata, hotel merupakan salah satu sarana produk dalam menydiakan penginapan, (Deborah,B \& Priscilla.B.: 1999). hotel memiliki pengertian yang berbeda bagi setiap orang. Sedangkan menurut Kamus Besar Bahasa Indonesia (KBBI) mengemukakan bahwa hotel adalah bangunan berkamar banyak yang disewakan sebagai tempat menginap dan makan bagi orang yang sedang dalam perjalanan.

Menurut AHMA (American Hotel and Motel Associations), hotel adalah suatu tempat dimana disediakan penginapan, makanan, dan minuman, serta pelayanan lainnya, untuk disewakan bagi para tamu atau orang orang yang tinggal untuk sementara waktu.

Menurut Budi, P., Agung (2013) Hotel adalah usaha yang bergerak dalam bidang jasa untuk mencari keuntungan melalui suatu pelayanan kepada para tamunya yang menginap seperti pelayanan resepsionis, tata graha, makan dan minum, MICE (Meeting, Incentive, Conferencing, and Exhibition), serta rekreasi. Dalam klasifikasi kelas Hotel Budget masuk pada kelas bintang 2 dan 3 .

Hotel Budget atau hotel kelas ekonomi adalah sebuah penyedia layanan dan jasa penginapan dengan 
tarif relatif terjangkau. Untuk menyediakan layanan atas kebutuhan tersebut Hotel Budget dirancang dengan kebutuhan seminimal mungkin dan sefungsional mungkin dalam operasinya. Hotel Budget tidak memiliki fasilitas selengkap ataupun semewah hotel internasional pada umumnya. Hotel Budget biasanya hanya dilengkapi fasilitas untuk menginap dan sarapan. Tetapi ada pula Hotel Budget yang tidak memiliki restoran atau area makan didalamnya karena pihak hotel hanya menghidangkan sarapan pagi untuk tamu di kamar masing-masing.

\section{Pentingnya Pendekatan Strategi}

Persaingan yang semakin ketat serta upaya-upaya untuk mempertahankan kepuasan tamu maka dunia perhotelan mengembangkan strategi terbaik yang disesuaikan dengan kekhasan pada bisnis yang digelutinya karena sesungguhnya strategi yang diterapkan oleh suatu organisasi akan memberikan hasil yang signifikan jika strategi yang dipilih tersebut merupakan strategi yang handal). sejalan dengan kondisi bisnis serta kekhasan dari bisnis yang digelutinya (Hidayat, M., \& Latief, F. : 2018), (Salusu, J : 1996), (Bracker, 1980) (Heene dkk, 2010) dan (Kurniawan dan Hamdani, 2000).

Saat ini banyak organisasi mengembangkan strategi yang komprehensif yang dimaksudkan untuk menyesuaikan dengan kebutuhan serta kekhasan dari organisasi tersebut, seperti strategi dengan pendekatan balanced scorecard, malcom baldrige, Kaizen dan six sigma strategi-strategi tersebut dewasa ini tidak hanya digunakan pada usaha korporasi, namun juga sudah digunakan pada berbagai sector organisasi dan usaha baik digunakan dalam pengelolaan strategi secara menyeluruh atau hanya digunakan pada sebagian dari fungsi organisasi tertentu saja yang menggunakannya (Hidayat, Musa, Haerani, \& Sudirman, 2015). Strategi Kaizen awalnya digunakan oleh dunia manufaktur di Jepang namun dewasa ini berbagai organisasi serta perusahaan non manufactur seperti hotel juga sudah menggunakan pendekatan strategi Kaizen dengan mengkaitkan prinsip prinsip kaizen dari sisi detil pelayanan yang sangat diharapkan oleh para tamu.

\section{Strategi Dengan Pendekatan Kaizen}

Kaizen (改善) secara harafiah berasal dari kata Kai (改) yang artinya perubahan dan Zen (善) yang artinya baik. Kaizen dapat diartikan secara singkat yaitu perbaikan atau peningkatan. Menurut Imai (1991:4), "kaizen berarti penyempurnaan berkesinambungan yang melibatkan setiap orang baik manajer maupun karyawan."Pada intinya kaizen adalah kesadaran bahwa manajemen harus memuaskan pelanggan dan memenuhi kebutuhan pelanggan, jika perusahaan ingin tetap eksis, memperoleh laba, dan berkembang.

Kaizen memiliki tujuannya yaitu menyempurnakan mutu, proses, sistem, biaya, dan penjadwalan demi kepuasan pelanggan. Metode yang digunakan dalam Kaizen untuk mencapai hal tersebut adalah dengan pertama, mengubah cara kerja karyawan sehingga karyawan bekerja lebih produktif, tidak terlalu melelahkan, lebih efisien, dan aman; kedua, memperbaiki peralatan; ketiga, memperbaiki prosedur. (Simanjuntak \& Hernita : 2008)

Kaizen menurut Imai (2008 : 11) adalah kemajuan dan perbaikan terus menerus dalam kehidupan seseorang, kehidupan berumah tangga, kehidupan 
bermasyarakat dan kehidupan kerja. Perbaikan terus menerus menurut Kaizen berlaku pada lima hal yaitu Seiri merupakan perbaikan dalam pemilihan, Seiton merupaan perbaikan dalam penataa, Seiso merupakan perbaikan dalam pembersihan, seiketsu merupakan perbaikan dalam pemantapan dan yang terakhir adalah Shitsuke yang merupakan perbaikan dalam pembiasaan

Cane (1998:36) menyatakan, Dalam perusahaan yang ingin menggunakan prisnip kaizen sudah menjadi tanggung jawab setiap orang untuk telibat dalam daur peningkatan. Mereka harus diberi ilmu pengetahuan, keahlian-keahlian dan peralatan agar sepenuhnya berpartisipasi bukan hanya berpartisipasi dalam tim mereka sendiri, tetapi juga berpartispasi dalam tim fungsional silang dan di seluruh organisasi sebagai satu kesatuan.

Intinya adalah bahwa manajemen harus memuaskan dan memenuhi kebutuhan pelanggan jika perusahaan ingin tetap bertahan dan berkembang. (Gasperz, Vincent.: 2005) Dengan kata lain dapat disimpulkan bahwa budaya Kaizen adalah proses perbaikan yang terjadi secara terus menerus untuk memperbaiki cara kerja, meningkatkan mutu dan produktivitas output dengan cara antara lain menanamkan sikap disiplin terhadap karyawan serta menciptakan tempat kerja yang nyaman bagi karyawan yang melibatkan semua anggota dalam hierarki perusahaan, baik manajemen maupun karyawan.

\section{Sasaran Akhir Dari Strategi Kaizen}

Karena kaizen berkaitan dengan perbaikan, kita harus memahami aspek bisnis apa yang paling penting untuk diperbaiki. Dan jawaban terhadap pertanyaan ini adalah kualitas, biaya dan penyerahan (quality, cost, deliveryQCD). Kualitas tidak hanya berkaitan dengan kualitas produk jadi atau jasa layanan, namun juga kualitas dari proses yang menghasilkan produk maupun jasa layanan tersebut. Biaya berkaitan dengan biaya keseluruhan, sejak dari merancang, memproduksi, menjual, dan memelihara produk atau jasa layanan tersebut. Penyerahan adalah menyerahkan produk atau jasa pelayanan secara tepat jumlah dan tepat waktu. Bila tiga kondisi yang dirumuskan dalam QCD itu terpenuhi, maka konsumen terpuaskan.

\section{METODE PENELITIAN}

Penelitian dilakukan di Hotel Ibis Budget Makassar dengan melibatkan sampel penelitian sebanyak 30 responden Pengambilan sampel dilakukan dengan accidental sampling, uji kualitas data dilakukan dengan uji validitas dan uji reliabilitas serta uji asumsi klasik yang meliputi Uji Normalitas (Kolmogorov-Smirnov), Uji Multikolinearitas (Nilai Tolerance dan VIF) Uji Heteroskedastisitas. Teknik analisis data secara kuantitatif dilakukan dengan menggunakan analisa Analisis Regresi Linier Berganda, pengujian hipoteis dilakukan dengan

menggunakan Uji Signifikansi Parsial $\left(\begin{array}{ll}\text { Uji } \\ \text { t) Uji Signifikansi Pengaruh }\end{array}\right.$ Simultan (Uji F) dan untuk mengetahui tingkat ketepatan hasil penelitian maka digunakan analisa Koefisien Determinasi (R2). (Ghozali, Imam : 2005)

Hipotesis dalam penelitian ini dirumuskan sebagai berikut:,

H1 : Diduga bahwa Seiri, Seiton, Seiso, Seiketsu dan Shitsuke berpengaruh secara parsial terhadap kepuasan tamu pada Hotel Budget di Kota Makassar

H2 : Diduga bahwa Seiri, Seiton, Seiso, Seiketsu dan Shitsuke berpengaruh secara simultan 
AkMen

terhadap kepuasan tamu pada Hotel Budget di Kota Makassar.

\section{HASIL PENELITIAN DAN} PEMBAHASAN

\section{Analisis Regresi Linier Berganda}

Hasil dari analisis regresi linear berganda sebagai berikut:

Tabel 1. Hasil Uji Regresi Linier Berganda

\begin{tabular}{|c|c|c|c|c|c|}
\hline \multirow[b]{2}{*}{ Model } & \multicolumn{2}{|c|}{$\begin{array}{c}\text { Unstandardized } \\
\text { Coefficients }\end{array}$} & \multirow{2}{*}{$\begin{array}{c}\begin{array}{c}\text { Standardi } \\
\text { zed } \\
\text { Coefficie } \\
\text { nts }\end{array} \\
\\
\text { Beta }\end{array}$} & \multirow[b]{2}{*}{$\mathrm{T}$} & \multirow[b]{2}{*}{ Sig. } \\
\hline & B & $\begin{array}{l}\text { Std. } \\
\text { Error }\end{array}$ & & & \\
\hline 1 (Constant) & 1.312 & .690 & & 1.902 & .064 \\
\hline Seiri & .537 & .063 & .399 & 8.564 & .000 \\
\hline Seiton & .121 & .062 & .106 & 1.954 & .057 \\
\hline Seiso & .328 & .067 & .271 & 4.883 & .000 \\
\hline Seiketsu & .463 & .075 & .319 & 6.146 & .000 \\
\hline Shitsuke & .124 & .077 & .083 & 1.608 & .115 \\
\hline
\end{tabular}

Sumber: data diolah tahun 2019

Berdasarkan pada tabel tersebut dapat diketahui nilai koefisien regresi seiri (X1) sebesar 0,537, seiton (X2) sebesar 0,121 , seiso (X3) sebesar 0,328, seiketsu (X4) sebesar 0,463 dan shitsuke sebesar 0,124 terhadap kepuasan tamu (Y) dengan nilai konstanta sebesar 1,312. Dengan demikian terbentuk persamaan regresi berikut:

$\mathrm{Y}=1,312+0,537+0,121+0,328+0,463+0,124+e$

1) Koefisien $X 1$ sebesar $+0,537$, artinya setiap penambahan sebesar satu kesatuan pada variable X1 akan menambah nilai $\mathrm{Y}$ sebesar 0,537 .

2) Koefisien $X 2$ sebesar $+0,121$, artinya setiap penambahan sebesar satu kesatuan pada variable X2

\section{Uji Parsial (Uji t)}

Uji t dikenal dengan uji parsial, yaitu untuk menguji bagaimana pengaruh masing-masing variabel bebasnya secara sendiri-sendiri terhadap variabel terikatnya. Uji ini dapat dilakukan dengan membandingkan $\mathrm{t}$ akan menambah nilai $\mathrm{Y}$ sebesar 0,121 .

3) Koefisien X3 sebesar + 0,328, artinya setiap penambahan sebesar satu kesatuan pada variable $\mathrm{X} 3$ akan menambah nilai $\mathrm{Y}$ sebesar 0,328 .

4) Koefisien $X 4$ sebesar $+0,463$, artinya setiap penambahan sebesar satu kesatuan pada variable $\mathrm{X} 4$ akan menambah nilai $\mathrm{Y}$ sebesar 0,463 .

5) Koefisien $X 5$ sebesar $+0,124$, artinya setiap penambahan sebesar satu kesatuan pada variable X5 akan menambah nilai $Y$ sebesar 0,124 .

6) Konstanta sebesar 1,312, artinya jika X1, X2, X3, X4 dan X5 =0 maka $Y=1,312$.

hitung dengan $\mathrm{t}$ tabel atau dengan melihat kolom signifikansi pada masing-masing t hitung. Adapun hasil dari pengujian parsial dengan menggunakan ibm spss 22 sebagai berikut: 


\begin{tabular}{|c|c|c|c|c|c|}
\hline \multirow[b]{2}{*}{ Model } & \multicolumn{2}{|c|}{$\begin{array}{l}\text { Unstandardize } \\
\text { d Coefficients }\end{array}$} & \multirow{2}{*}{$\begin{array}{c}\text { Standar } \\
\text { dized } \\
\text { Coeffic } \\
\text { ients } \\
\text { Beta }\end{array}$} & \multirow[b]{2}{*}{$\mathrm{T}$} & \multirow[b]{2}{*}{ Sig. } \\
\hline & B & $\begin{array}{l}\text { Std. } \\
\text { Error }\end{array}$ & & & \\
\hline 1 (Constant) & 1.312 & .690 & & $\begin{array}{r}1.90 \\
2\end{array}$ & .064 \\
\hline Seiri & .537 & .063 & .399 & $\begin{array}{r}8.56 \\
4\end{array}$ & .000 \\
\hline Seiton & .121 & .062 & .106 & $\begin{array}{r}1.95 \\
4\end{array}$ & .057 \\
\hline Seiso & .328 & .067 & .271 & $\begin{array}{r}4.88 \\
3\end{array}$ & .000 \\
\hline Seiketsu & .463 & .075 & .319 & $\begin{array}{r}6.14 \\
6\end{array}$ & .000 \\
\hline Shitsuke & .124 & .077 & .083 & $\begin{array}{r}1.60 \\
8\end{array}$ & .115 \\
\hline
\end{tabular}

Sumber: data diolah tahun 2019

Berdasarkan hasil pengolahan data yang terdapat pada tabel diatas diperoleh nilai thitung variabel seiri sebesar 8,564, variabel seiton sebesar 1,954, variabel seiso sebesar 4,883, variabel seiketsu sebesar 6,146 dan variabel shitsuke sebesar 1,608. Dengan demikian pengujian hipotesis untuk mengetahui apakah variabel independen berpengaruh signifikan terhadap variabel dependen dalam penelitian ini dijelaskan melalui perbandingan antara nilai $t$ table dengan nilai $t$ hitung jika nilai t hitung lebih besar dari pada nilai $\mathrm{t}$ table maka hal tersebut membuktikan hipotesis alternative penelitian diterima dan hipotesis nul ditolak penerimaan dan penolakan hipotesis alternative dilaukan melalui table sebagai berikut :

Tabel.3.Penerimaan/Penolakan Hipotesis Alt

\begin{tabular}{|l|l|l|l|}
\hline Variabel & T Hitung & T Tabel & Hipotesis alt \\
\hline Seiri & 8,564 & 2,0423 & Ha diterima \\
\hline Seiton & 1,954 & 2,0423 & Ha diterima \\
\hline Seiso & 4,883 & 2,0423 & Ha diterima \\
\hline Seketsu & 6,146 & 2,0423 & Ha diterima \\
\hline Shitsuke & 1,608 & 2,0423 & Ha ditolak \\
\hline
\end{tabular}

Melalui tebel diatas terbukti bahwa secara parsial variable Seiri Seiton Seiso dan Seketsuberpengaruh terhadap terhadap kepuasan tamu sedangkan variable Shitsuke terbukti secara parsial tidak berpengaruh terhadap kepuasan tamu. Dengan nilai signifikansi lebih kecil atau sama dengan 0.05 untuk variable Seiri, Seiton Seisodan Seiketsu hal ini menunjukkan bahwa pengaruh untuk keempat variable tersebut terhadap kepuasan tamu adalah signifikan sementara untuk variable Shitsuke yang memiliki nilai signifikansi sebesar 0,115 hal ini menunjukkan bahwa pengaruh Shitsuke terhadap kepuasan tamu adalah tidak signifikan

\section{Uji Simultan (Uji F)}

Uji F dilakukan untuk mengetahui pengaruh variabel bebas (independen) secara bersama-sama berpengaruh terhadap variabel terikat (dependen). Untuk mengetahui hal tersebut dapat dirumuskan hipotesis sebagai berikut:

1. H0: Tidak ada pengaruh signifikan seiri, seiton, seiso, seiketsu dan shitsuke secara bersama-sama terhadap kepuasan tamu.

2. Ha: Ada pengaruh signifikan seiri, seiton, seiso, seiketsu dan shitsuke 
secara bersama-sama terhadap

kepuasan tamu.

Untuk mengetahui pengaruh variabel X (seiri, seiton, seiso, seiketsu, dan shitsuker) secara bersama-sama terhadan variabel $\mathrm{Y}$ (kepuasan tamu) sebagai berikut:
1. Jika nilai sig $<0,05$, atau $\mathrm{F}$ hitung $>\mathrm{F}$ tabel maka $\mathrm{Ha}$ diterima dan Ho ditolak.

2. Jika nilai sig $>0,05$, atau $\mathrm{F}$ hitung $<\mathrm{F}$ tabel maka H0 diterima dan Ha ditolak.

Tabel 4. Hasil Uji Simultan (Uji F)

\begin{tabular}{|l|r|r|r|r|r|}
\hline Model & $\begin{array}{c}\text { Sum of } \\
\text { Squares }\end{array}$ & Df & $\begin{array}{c}\text { Mean } \\
\text { Square }\end{array}$ & F & Sig. \\
\hline 1 Regression & 388.559 & 5 & 77.712 & 151.56 & $.000^{\mathrm{b}}$ \\
& 22.561 & 44 & .513 & & \\
$\quad$ Residual & & & \\
Total & 411.120 & 49 & & & \\
\hline
\end{tabular}

Sumber: data diolah tahun 2019

Berdasarkan perhitungan secara simultan diperoleh $F$ hitung sebesar 151,561 dan nilai signifikan sebesar 0,000. Dengan demikian H0 ditolak dan Ha diterima karena lebih kecil dari tingkat signifikansi $(0,000<0,05)$ dan $\mathrm{F}$ hitung lebih besar dari $\mathrm{F}$ tabel $(5,036>$ $2,40)$. Jadi dapat disimpulkan bahwa ada pengaruh signifikan variabel seiri, seiton, seiso, seiketsu dan shitsuke secara bersama-sama terhadap kepuasan tamu.

\subsubsection{Koefisien Determinasi $\left(R^{2}\right)$}

Koefisien determinasi $\left(R^{2}\right)$ pada intinya mengukur seberapa jauh kemampuan model dalam menerangkan variasi variabel dependen. Berikut tabel 4.19 yang menampilkan hasil koefisien determinasi $\left(R^{2}\right)$ dari spss 22 :

\section{Tabel 4. Hasil Koefisien Determinasi}

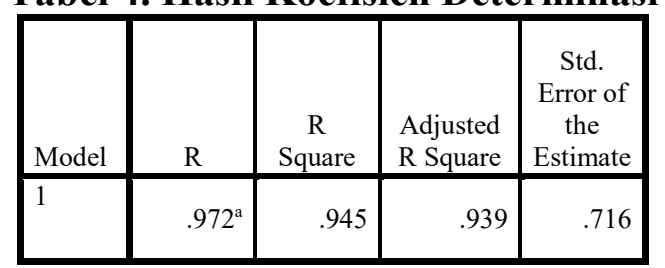

Sumber: data diolah tahun 2019

Dari data pada tabel di atas (Model Summary) tersebut diketahui nilai Adjusted $R$ Square $\left(\mathrm{R}^{2}\right)$ sebesar 0,945 . Berdasarkan nilai Adjusted $\mathrm{R}$ Square $\left(\mathrm{R}^{2}\right)$ ini dapat dikatakan bahwa sebesar 94,5\% variabel seiri, seiton, seiso, seiketsu dan shitsuke mampu menjelaskan variabel kepuasan tamu. Sedangkan sisanya 5,5 (100\% - 94,5\%) dijelaskan oleh faktor lain yang tidak dimasukkan atau diamati dalam penelitian ini.

\section{Pembahasan}

Strategi Kaizen merupakan strategi yang tepat untuk digunakan pada bisnis perhotelan hal ini karena unsur-unsur Kaizen sangat berkaitan dengan permasalhan hospitality yang memerlukan komitmen dalam hal pelayanan sebagai suatu contoh Seiri yang dikaitkan dengan pemilihan maka pemilihan akan bahan-bahan atau alatalat dan juga tema tema sangat tepat digunakan dalam industry pelayanan yang harus mengedepankan kualitas kemudian Seiton yang berarti penataan, penataan yang indah dan rapih juga 
merupakan suatu mentuk komitmen terhadap pelayannan begitu pula Seiso yang berarti pembersihan salah satu factor yang akan menjadi kepuasan tamu pada hotel adalah masalah kebersihan, seiketsu yang berarti pemantapan konsep ini akan mengarahkan pada komitmen untuk memberikan yang terbaik sebagai sebuah kemantapan yang menjadi budaya kerja dan yang terakhir Shiketsu yang merupakan pembiasaan hal ini sangat berkaitan dengan konsistensi pelayanan. Dalam penelitian ini dibuktikan bahwa kelima unsur Kaizen tersebut terbukti memiliki pengaruh yang positif terhadap kepuasan pelanggan. Hanya satu variable yang memiliki pengaruh positif namun tidak signifikan yaitu Shiketsu yang berarti pembiasaan sehingga hal ini harus menjadi masukan bagi manajemen agar pembiasaan yang menjadi komitmen serta konsistensi untuk memberikan pelayanan terbaik harus semakin ditingkatkan .

\section{KESIMPULAN DAN SARAN \\ Kesimpulan}

Adapun hasil kesimpulan dari penelitian ini adalah :

1. Terdapat pengaruh positif dan signifikan atara Seiri Seiton Seiso Seiketsu dan Shitsuke secara parsial terhadap kepuasan tamu pada hotel Ibis budget Makassar Airport.

2. Terdapat pengaruh Seiri (X1), Seiton (X2), Seiso (X3), Seiketsu (X4) dan shitsuke (X5) terhadap kepuasan tamu (Y) secara simultan pada hotel Ibis budget Makassar Airport.

\section{Saran-Saran}

Berdasar pada hasil penelitian ini maka disarankan bahwa penerapan strategi kaizen yang sudah terbukti efektif dalam menjaga kepuasan pelanggan perlu untuk terus ditingkatkan manajemen perllu lebih memperhatikan konsep Shitsuke yang masih belum memiliki pengaruh terhadap tingkat kepuasa tamu.

\section{DAFTAR PUSTAKA}

Masaaki lmai, (1991). Kaizen Kunci Sukses Jepang dalam Persaingan. Jakarta: PT Pustaka Binaman Pressindo.

http://www.jpnn.com/news/potensi-

hotel-budget-besar.
pada tanggal 2 November
2018 .

Deborah,B \& Priscilla.B. (1999). "TQM in American Hotels". Cornel Hotel \& Restaurant Administration Quarterly (CHR). Vol.39. Issue 1 Februari 1998.

Budi, P., Agung. (2013). Manajemen Marketing Perhotelan.

Yogyakarta: ANDI

Hidayat, M., \& Latief, F. (2018). STRATEGI PENINGKATAN JUMLAH HUNIAN HOTEL DENGAN ANALISIS SWOT. PARADOKS: Jurnal Ilmu Ekonomi, 1(1), 15-27.

Risma A. Simanjuntak, Dian Hernita."USULAN

PERBAIKAN METODE KERJA BERDASARKAN MICROMOTION STUDY DAN PENERAPAN METODE 5S UNTUK MENINGKATKAN PRODUKTIFITAS". Jurnal Teknologi, Volume. 1 Nomor 2 , Desember 2008, 191 - 203. 
Salusu, J. (1996). Pengambilan Keputusan Stratejik. Jakarta: Gramedia Widiasarana Indonesia.

Heene, Aimè dkk, (2010). Manajemen Strategik Keorganisasian Publik. Bandung: PT Refika Aditama.

Kurniawan, Fitri Lukiastuti dan Hamdani, Muliawan, (2000). Manajemen Stratejik dalam Organisasi. Yogyakarta: MedPress.

Hidayat, M., Musa, C. I., Haerani, S., \& Sudirman, I. (2015). The Design of Curriculum Development Based on Entrepreneurship through Balanced Scorecard Approach. International Education Studies, 8(11), 123. https://doi.org/10.5539/ies.v8n1 $1 \mathrm{p} 123$

Masaaki Imai, (2008). Budaya Kaizen, Jakarta: Pustaka Utama.

Cane, Sheila. (1998). "Strategi Kaizen untuk Menang Melalui Manusia”. :Interaksara.
Gasperz, Vincent. (2005). Total Quality Management. Jakarta : PT. Gramedia Pustaka Utama.

Ghozali, Imam. (2005). Aplikasi Analisis Multivariat dengan Program SPSS edisi ke-3. Badan Penerbit Undip. Semarang.

Kamus Besar Bahasa Indonesia, (1989) Departemen Pendidikan dan Kebudayaan, Jakarta.

Kaplan. Robert S dan David Norton. (2000), Balanced Scorecard: Menerapkan Strategi Menjadi Aksi, Terjemahan oleh Peter R. Yosi Pasla dari Balanced Scorecard: Transalting Strategi Into Action (1996), Erlangga, Jakarta.

Salusu, J.(2015). Pengambilan Keputusan Stratejik Untuk Organisasi Publik dan Organisasi Nonprofit. Jakarta: Gramedia Widiasarana Indonesia. 